\title{
Nitrogen fertilizer levels and some weed control treatments effects on barley and associated weeds
}

\author{
${ }^{*}$ EI-Metwally, I. M. ; ${ }^{1}$ M. S. Abd El-Salam ${ }^{2}$ and R. M. H. Tagour ${ }^{3}$ \\ ${ }^{1}$ Botany Dept., National Research Centre, Cairo, Egypt. \\ ${ }^{2}$ Field Crop Research Dept., National Research Centre, Cairo, Egypt. \\ ${ }^{3}$ Weed Research Laboratory, Agricultural Research Centre, Giza, Egypt. \\ *Corresponding author: im elmetwally@yahoo.com \\ ABSTRACT
}

Studies were carried out to investigate the efficiency of nitrogen fertilizer levels $(15,30,45$ and $60 \mathrm{~kg} / \mathrm{fed}$ ) and different postemergence herbicides (metosulam, sulfamoylurea, fenoxaprop-pethyl, clodinafop-propargyl, isoproturon + diflufinican and isoproturon), hand weeding and unweeded check in barley crop at private farms in Shalakan, Kalubia Governorate, Egypt during $2007 / 2008$ and 2008/2009 seasons. Increasing N- levels from 15 to 30,45 and $60 \mathrm{~kg} / \mathrm{fed}$ significantly increased number and dry weight of barley weeds after 60 and 90 days from sowing (DFS). Application of $60 \mathrm{~kg} \mathrm{~N} / \mathrm{fed}$ recorded the highest number and dry weight of weeds. Metosulam at $0.04 \mathrm{~L} / \mathrm{fed}$ provided control (95.46 - 92.83\% reduction in dry weight after 60 and 90 DFS) for broadleaved weeds but failed to completely control narrow-leaved weeds. Clodinafoppropargyl at $140 \mathrm{~g} / \mathrm{fed}$ provided 94.85 and $94.34 \%$ reduction in dry weight after 60 and 90 DFS of narrow leaf weeds. Isoproturon + diflufinican came in the first order for controlling total weeds but statistically leveled with isoproturon alone. It recoded number and dry weight of total weeds than unweeded by 90.31 and $91.46 \%$ after 60 days from sowing and 89.78 and $90.80 \%$ after 90 days from sowing. pplication of nitrogen at $60 \mathrm{~kg} \mathrm{~N} / \mathrm{fed}$ recorded the highest value of flag leaf area, plant height, spike length, number of grains/spike, grains weight $/$ spike, spikes number $/ \mathrm{m}^{2}$, straw and grain yields as well as grain protein and total carbohydrates percentage. All herbicidal treatments and hand weeding increased significantly growth, yield, yield components and chemical composition of grain barley. Isoproturon + diflufinican was superior treatment for increasing plant height, spike length, grains number /spike, grains weight /spike, spikes number $/ \mathrm{m}^{2}$, straw and grain yields as well as grain protein and total carbohydrates percentage. While, hand weeding recorded the highest values of flag leaf area. Application of isoproturon + diflufinican herbicide provided $66.3 \%$ more grain yield than weedy check. The interaction between $\mathrm{N}$-levels and weed management treatments had significant effect on total dry weight of weeds, spikes number $/ \mathrm{m}^{2}$, grain weight /spike and grain and straw yields. Isoproturon + diflufinican produced the lowest values of total dry weight of weeds after 60 and 90 DFS when 15 $\mathrm{kg} \mathrm{N} / \mathrm{fed}$ was added. While, Application of $60 \mathrm{~kg} \mathrm{~N} / \mathrm{fed}$ gave the maximum values of number of spike $/ \mathrm{m}^{2}$, weight of grain /spike, grain and straw yields/fed when isoproturon + diflufinican treatment was applied. It could be concluded that using $60 \mathrm{~kg} \mathrm{~N} / \mathrm{fed}$ resulted in increment of growth and productivity of barley crop when isoproturon + diflufinican treatment was used.

Keywords: Nitrogen fertilizer, weed control, barley

\section{INTRODUCTION}

Barley (Hordeum vulgare L.) is one of the most important winter crops grown for green forage as for feeding animals on its straw beside grains, also as a food by Arabian tribes who live in the desert and in dry regions for making bread, either alone or mixed with wheat. Also, it could be used for malting in the brewing industry. Nitrogen fertilizer level and weed control treatments are among the important factors affecting barley productivity. Nitrogen as constituents plant proteins, chlorophyll, nucleic acids and other substances is considered the most important nutrients. Nitrogen fertilizer contributed greatly to improve grain yield. Although nitrogen fertilizer effects on barley productivity have bean exclusively studied, further studies on determining the optimum nitrogen levels is still needed. Improving barley growth, yield and its components due to increasing nitrogen supply was achieved by Megahed, 2003. Increasing $\mathrm{N}$ - fertilizer levels from 0 to 30 and 45 
$\mathrm{kg} / \mathrm{fed}$ significantly increased grain, straw yield and grain protein content of barley (Youssef et al., 2004) . Weed control play an active role in raising grain yield, since weeds cause great losses in yield reached 48.9 $\%$ (Metwally et al., 2000). Hand labor became scarce and costly, herbicides replaced it as a cheap and easy method of weed control in barley fields. ElBawab and Kholousy (2003) reported that controlling weeds by herbicidal treatments increased grain yield by about 40.3 and $13.6 \%$, compared with unweeded and hand weeding treatments, respectively. Several herbicides are available to control barley weeds. Metosulam and sulfamoylurea herbicides were introduced as new selective herbicides for controlling broadleaved weeds in cereals (El-Metwally, 2002). Application of metosulam herbicide provided $100 \%$ broadleaved weed control and gave $20 \%$ more wheat yield than weedy check (EL-Metwally and Soudy, 2009). Fenoxaprop-p-ethyl and clodinafop-propargyl are two selective herbicides for control of grasses weeds in wheat and barley (Nassar, 2008). ElMetwally and El-Rokiek (2007) found that the two herbicides provided control of narrow leaf weeds (97.7\% reduction in dry weight after 90 DFS). Isoproturon + diflufinican and isoproturon are two selective herbicides for control of grasses and broadleaved weeds in cereals (El-Metwally and Soudy, 2009). Application of isoproturon + diflufinican or isoproturon alone significantly decreased broadleaved and grasses weeds and improved growth, yield and its components of barley crop (Abou El-Defan and El-Desoki, 2000; Metwally et al., 2000 and Muhammad et al., 2007). The objectives of this investigation were to study the response of barley and the accompanied weeds to nitrogen fertilizer levels and some weed control treatments.

\section{MATERIALS AND METHODS}

Two field experiments were conducted at private farms in Shalakan, Kalubia Governorate, Egypt during the 2007/2008 and 2008/2009 seasons. The soil texture was clay loam and the preceding crop was soybean in both seasons. Each experiment included 32 treatments which were the combinations of :

1- Four nitrogen fertilizer levels, i.e. 15, 30, 45 and 60 $\mathrm{kg} \mathrm{N} / \mathrm{fed}$. The nitrogen fertilizer was used in the form of ammonium nitrate $(33.5 \% \mathrm{~N})$ was added in two equal portions, before first and second irrigation.

2- Eight weed management treatments (metosulam at $0.04 \mathrm{~L} / \mathrm{fed}$, sulfamoylurea at $100 \mathrm{~g} / \mathrm{fed}$, fenoxaprop-p-ethyl at $0.5 \mathrm{~L} / \mathrm{fed}$, clodinafop-propargyl at $140 \mathrm{~g} / \mathrm{fed}$, isoproturon + diflufinican at $0.6 \mathrm{~L} / \mathrm{fed}$, isoproturon at $1.25 \mathrm{~L} / \mathrm{fed}$, hand weeding once at 45 days from sowing and weedy check (unweeded). The common, trade and chemical names of herbicides are shown in Table (1). All herbicides were sprayed postemergence at 25 days from sowing (DFS), excepted clodinafop-propargyl were sprayed as postemergence at 50 DFS, using a knapsack sprayer with one nozzle and 200 liters water/fed. A split-plot design with four replicates was used, the main plot were occupied by nitrogen fertilizer levels, while weed management treatments were allocated in split plot ones. The experimental unit area was $10.5 \mathrm{~m}^{2}$. Barley grains Giza 2000 cultivar were broadcasted at a rate of $50 \mathrm{~kg} / \mathrm{fed}$, then followed by irrigation. The sowing date was Nov. $27^{\text {th }}$ and $30^{\text {th }}$ in the $1^{\text {st }}$ and $2^{\text {nd }}$ seasons, respectively. All other recommended cultural practices were adopted throughout the two seasons.

Table (1): Common, trade and chemical names of used herbicides.

\begin{tabular}{|c|c|c|}
\hline Common name & Trade name & Chemical name \\
\hline Metosulam & $\begin{array}{l}\text { Sinal } \\
10 \% \text { SC }\end{array}$ & $\begin{array}{l}\mathrm{N}-(2, \quad \text { 6-dichloro- } 3-\text { methyl phenyl)-5,7-dimethoxy[1, } 2, \\
\text { 4]triazolo[1,5-a] pyrimidine-2-sulfonamide }\end{array}$ \\
\hline Sulfamoylurea & Gopter 10\% WP & $\begin{array}{l}\text { (1-((o-cyclopropylcabonyl) phenyl) sulfamoyl)-3-(4,6- } \\
\text { dimethoxy-2-pyrimidinyl)-urea) }\end{array}$ \\
\hline Fenoxaprop & Puma super $7.5 \% \mathrm{EW}$ & $\begin{array}{l}( \pm)-2-[4-[(6-c h l o r o-2-b e n z o x a z o l y l) o x y] \\
\text { acid }\end{array}$ \\
\hline Clodinafop-propargyl & $\begin{array}{l}\text { Topic } \\
15 \% \text { WP }\end{array}$ & $\begin{array}{l}-2-(4-((5-c h l o r o-3-f l u o r o-2-p y r i d i n y l) o x y) p h e n o x y) p r o p i o n i c \\
\text { acid }\end{array}$ \\
\hline $\begin{array}{l}\text { Isoproturon+ } \\
\text { diflufinican }\end{array}$ & $\begin{array}{l}\text { Panther } \\
55 \% \text { SC }\end{array}$ & $\begin{array}{l}\text { [3-(4-isopropyl phenyl)-1,1-dimethyl urea] } \\
\text { +2,4-difluoro-2-(alpha,alpha,alpha-trifluoro-m } \\
\text { tolyloxy)nicotinanilide }\end{array}$ \\
\hline Isoproturon & Arelon $50 \% \mathrm{FL}$ & [3-(4-isopropyl phenyl)-1,1-dimethyl urea] \\
\hline
\end{tabular}

Weeds were hand pulled from one square meter of each experimental unit at 60 and 90 days after sowing, then identified and classified into grasses and broad-leaved groups. Number and dry weight of 
weeds were recorded after drying in a forced draft oven at $70^{\circ} \mathrm{C}$ for 72 hours. After heading stage, flag leaf area $\left(\mathrm{cm}^{2}\right)$ was measured on ten tillers chosen randomly from each plot. Harvesting date was May $15^{\text {th }}$ and $7^{\text {th }}$ in the $1^{\text {st }}$ and $2^{\text {nd }}$ seasons, respectively, where plants of square meter per each experimental plot were collected to estimate spikes number $/ \mathrm{m}^{2}$, straw yield ton / fed and grain yield ardab / fed. Afterward, ten shoots were taken from each and the following traits were measured: plant height, spike length, grains number/spike and grain weight /spike.

Total nitrogen was determined according to A.O.A.C. (1980). N values were multiplied by the factor of 5.82 to obtain protein percentage. Phosphorus and potassium percentage were determined according to Cottenie et al. (1982). Total carbohydrate in grains was determined according to Dubois et al. (1956).

The combined analysis of variance for the data of the two seasons were performed after testing the error homogeneity and LSD at 0.05 level obtained data from each season were subjected to the proper statistical analysis of variance of significance was used for the comparison between means according to Gomez and Gomez (1984).

\section{RESULTS AND DISCUSSION}

Weed growth: The most commonly surveyed weeds in the experimental situations through the two growing seasons were: bristle-spiked (Phalaris paradoxa, L.), wild oat (Avena fatua, L.) and annual bluegrass (Poa annua, L.), as grasses and burclover (Medicago polymorpha, L.) and lambsquarters (Chenopodium album, L.) as broadleaf weeds. The dry weight of grass weed species less than broadleaved weed species as shown in unweeded treatment (Table 2).

Effect of nitrogen levels: The results clear that nitrogen levels caused a significant effect on number and dry weight of broadleaved, grasses and total weeds. Application of $60 \mathrm{~kg} \mathrm{~N} / \mathrm{fed}$ markedly increased number and dry weight of weeds after 60 and 90 DFS. In contrast, the lowest values of number and dry weight of weeds after 60 and 90 DFS recorded when using of $15 \mathrm{~kg} \mathrm{~N} / \mathrm{fed}$. These results are in general agreement with those recorded by Turk et al. (2003); Blackshaw and Brandt (2008) and Nassar (2008).

Effect of weed managements: Data in Table 2 reveal that all weed control treatments decreased significantly the number and dry weight of broadleaved weeds after 60 and 90 DFS as compared to the unweeded check. Application of metosulam, sulfamoylurea, isoproturon + diflufinican and isoproturon herbicides recorded the highest significant reduction in both number and dry weight of broadleaved weeds. Metosulam gave 95.5 and 92.8 $\%$ reduction in dry weight of broadleaved after 60 and 90 DFS. The herbicides used in the present work have different targets in plants. These target sites are acetolactate synthase (metosulam) the key plant enzyme.

inhibiting branched chain amino acids leucine, isoleucine and valine (Buker et al., 2004) and the plant enzyme protoporphyrinogen oxidase (Ivany, 2005); sulfamoylurea inhibition of acetohydroxyacid synthase, the key plant enzyme amino acids biosynthesis. Confirming results in this respect were cited by Hussein and El-Desoki (2001), El-Metwally (2002) and El-Metwally and El-Rokiek (2007).

As indicated in Table (2), the application of all herbicides and hand weeding application were found to reduce significantly both number and dry weight of grasses. Maximum significant reduction in dry weight was realized by clodinafop-propargyl where it recorded 94.9 and $94.3 \%$ after 60 and 90 DFS, compared to unweeded control. In addition, fenoxaprop-p-ethyl spraying induced great significant inhibition (94.7 and 94.2\%) in dry weight of weeds at 60 and 90 DFS. These herbicides have definite target sites resulting in the inhibition of, for example, the synthesis of fatty acids ((e.g, diclofop methyl or clidinafop-propargyl), inhibits Acetyl Co Enzyme Carboxylase (ACCase), the enzyme catalyzing the first committed step in fatty acids synthesis (fenoxaprop-p-ethyl). Inhibition of fatty acid synthesis presumably blocks the production of phospholipids used in building new membranes required for cell growth (WSSA, 1994). Similar results were obtained by Ram et al., 2002; Bailey and Wilson, 2003; Ali et al., 2004 and Singh, 2004.

The data in Table (2) show that all weed control treatments decreased significantly the total weeds (number and dry weight) after 60 and 90 DFS in comparison to the unweeded control. The highest significant reductions in total dry weight were obtained by isoproturon + diflufinican ( 91.5 and 90.8 $\%$ ), isoproturon (87.8 and $86.4 \%$ ) and metosulam (85.5 and $72.7 \%$ ), respectively in comparison with unweeded control in the combined of the two seasons. Isoproturon + diflufinican and isoproturon used in the present work have different targets in 
plants. These target sites diflufenican inhibits the carotenoid synthesis in plants. Isoproturon interferes with the photosynthetic process. Susceptible species develop chlorosis. Isoproturon is effective even at relatively low temperatures and is not affected by light intensity. High soil humidity favors efficacy. Muhammad et al (2007) reported that isoproturon + diflufinican was highly efficient in controlling annual grasses and broadleaved weeds grown in some fields crops (wheat and barley). So, isoproturon + diflufinican was more effective in controlling total weeds and resulted in the highest reduction in dry matter compared with other treatment. The reduction in weed dry weight might be due to the inhibition effect of herbicide treatment on growth and development of weeds. These results are in general agreement with those recorded by Turk et al (2003); Nassar (2008) and EL-Metwally and Soudy (2009).

Interaction effect: Data in Fig.1 show that there were significant effect of the interaction between nitrogen levels and weed control treatments on total dry weight of weeds after 60 and 90 DFS. Application of $15 \mathrm{~kg} \mathrm{~N} / \mathrm{fed}$ markedly decreased total dry weight of barley weeds when isoproturon + diflufinican was used. While, the highest total dry weight of barley weeds was recorded when addition of $60 \mathrm{~kg} \mathrm{~N} / \mathrm{fed}$ in unweeded treatment. Similar results were obtained by El-Metwally (1998) and Turk et al. (2003).

\section{Barley: \\ Barley growth:}

Effect of nitrogen levels: Application of nitrogen at $60 \mathrm{~kg} / \mathrm{fed}$ gave the greatest values of flag leaf area and plant height (Table 3). Vice- versa addition of 15 $\mathrm{N} \mathrm{kg/fed} \mathrm{recoded} \mathrm{the} \mathrm{lowest} \mathrm{values} \mathrm{of} \mathrm{the} \mathrm{previous}$ characters. The increment in growth characters due to nitrogen fertilizer enables the plants to absorb balanced nutrients, which promotes the photosynthesis and accumulation of assimilates and a consequence growth was enhanced. These results are in accordance with those recorded by Turk et al. (2003); Blackshaw and Brandt (2008) and Nassar (2008).

Effect of weed management: Results in Table 3 illustrate significant impact of weed control treatments on flag leaf area and plant height. Hand weeding exceeded the rest of other weeded practices for enhancing flag leaf area. While, isoproturon + diflufinican gave the highest value of plant height. The enhancement of wheat growth in the weeded plots might be attributed to the efficiency in weed elimination (Table, 2), and consequently the reduction of weed competitive ability against barley plants. Such conditions mean more efficient use of the environmental growth factors by barley plants reflecting on improving their growth. These results are in good harmony with those of Metwally et al. (2000); Turk et al. (2003) and Rashid and Khan (2008).

\section{Barley yield and its attributes:}

Effect of nitrogen levels: Data presented in Table 3 show significant increases of all the studied traits with increasing $\mathrm{N}$ - levels from 15 to $60 \mathrm{~kg} \mathrm{~N} / \mathrm{fed}$. Application of $60 \mathrm{~kg} \mathrm{~N} / \mathrm{fed}$ led to the significantly increased maximum values of spike length, number of grains/spike, grain weight/spike, number of spikes $/ \mathrm{m}^{2}$, grain and straw yields. On the other hand, the lowest of aforementioned characters was obtained by addition of $15 \mathrm{~kg} \mathrm{~N} / \mathrm{fed}$. The increase in barley yield with increasing $\mathrm{N}$-levels might due to promotes tillering in cereals and encourages the formation of more spikes/plant and increasing grain yield /plant could be attributed to its simulative effect of the vegetative growth which increased the photosynthetic rate, spikes number/plant, number of spikletes/spike spike length and grains number /spike may account for the superiority of grain yield. Similar results were reported by Turk et al. (2003) Abd Alla, (2004); Khedr and Nemeat Alla, (2006); El-Sheref et al. (2007); Blackshaw and Brandt (2008) and Nassar (2008).

Effect of weed management: Highest values of spike length, grains number /spike, grains weight/spike, spikes number $/ \mathrm{m}^{2}$, grain and straw yields/fed were obtained from isoproturon+ diflufinican, followed by isoproturon, hand weeding and metosulam. Whereas, the lowest values of the previous characters was obtained from the unweeded check (Table 3). Isoproturon + diflufinican, isoproturon, hand weeding and metosulam treatments gave higher values of grain yield /fed. They significantly increased grain yield /fed over the unweeded check by $66.3,62.0,37.6$ and $34.5 \%$, respectively. Such superior weeded treatments minimized weed-crop competition (Table, 2) and saved more available environmental resources for crop plants that improved growth traits (Table, 3 ). This in turns increased flag leaf area at heading stage, plant height (at harvest) and produced more assimilates synthesized, translocated, and accumulated in various plant organs which positively reflected on straw and grain yields/fed. The positive effect of weeded practices on barley yields and its components have been confirmed by Metwally et al. (2000); Turk et al. (2003) and El-Metwally and ElRokiek (2007). 
Agric. Biol. J. N. Am., 2010, 1(5): 992-1000

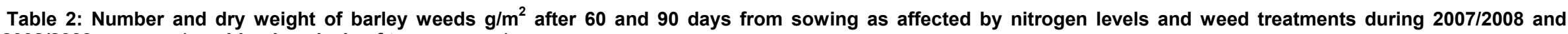
$2008 / 2009$ seasons (combined analysis of two seasons).

\begin{tabular}{|c|c|c|c|c|c|c|c|c|c|c|c|c|}
\hline \multirow[t]{3}{*}{ Treatments } & \multicolumn{6}{|c|}{ At 60 days from sowing } & \multicolumn{6}{|c|}{ At 90 days from sowing } \\
\hline & \multicolumn{3}{|c|}{ Number of weeds } & \multicolumn{3}{|c|}{ Weight of weeds (g) } & \multicolumn{3}{|c|}{ Number of weeds } & \multicolumn{3}{|c|}{ Weight of weeds(g) } \\
\hline & Broad & Grasses & Total & Broad & Grasses & Total & Broad & Grasses & Total & Broad & Grasses & Total \\
\hline \multicolumn{13}{|l|}{ Nitrogen levels: } \\
\hline $15 \mathrm{~kg} \mathrm{~N} / \mathrm{fed}$ & 13.40 & 5.00 & 18.40 & 19.33 & 6.33 & 25.66 & 15.10 & 7.80 & 22.90 & 23.97 & 9.46 & 33.43 \\
\hline $30 \mathrm{~kg} \mathrm{~N} / \mathrm{fed}$ & 15.20 & 5.90 & 21.10 & 26.61 & 7.40 & 34.01 & 16.30 & 8.62 & 24.92 & 33.48 & 15.13 & 48.61 \\
\hline $45 \mathrm{~kg} \mathrm{~N} / \mathrm{fed}$ & 17.50 & 7.30 & 24.80 & 35.32 & 10.48 & 45.80 & 20.80 & 9.60 & 30.40 & 41.52 & 23.32 & 64.84 \\
\hline $60 \mathrm{~kg} \mathrm{~N} / \mathrm{fed}$ & 18.00 & 8.70 & 26.70 & 43.22 & 12.91 & 56.13 & 23.70 & 10.90 & 34.60 & 48.90 & 28.48 & 77.38 \\
\hline F-Test & ** & $* *$ & ** & ** & ** & ** & ** & ** & ** & ** & ** & ** \\
\hline LSD 5\% & 0.47 & 0.96 & 1.51 & 1.83 & 0.81 & 1.76 & 1.75 & 1.13 & 1.94 & 2.10 & 1.03 & 2.82 \\
\hline \multicolumn{13}{|c|}{ Weed control: } \\
\hline Metosulam & 2.40 & 10.0 & 12.40 & 4.37 & 13.13 & 17.50 & 4.16 & 14.70 & 18.86 & 7.57 & 34.71 & 42.28 \\
\hline Sulfamoylurea & 3.70 & 11.60 & 15.30 & 5.12 & 15.09 & 20.21 & 5.20 & 15.20 & 20.40 & 9.95 & 35.67 & 45.62 \\
\hline Fenoxaprop-p- ethyl & 22.80 & 0.25 & 23.05 & 49.43 & 1.26 & 50.69 & 27.10 & 0.70 & 27.80 & 54.10 & 12.89 & 56.99 \\
\hline Clodinafop-propagyl & 25.10 & 0.20 & 25.30 & 54.56 & 1.23 & 55.79 & 28.90 & 0.65 & 29.55 & 62.72 & 2.80 & 65.52 \\
\hline Isoproturon.+Diflufinican & 4.80 & 1.80 & 6.60 & 7.92 & 2.35 & 10.27 & 5.60 & 2.70 & 8.30 & 10.19 & 4.08 & 14.27 \\
\hline Isoproturon & 7.90 & 3.00 & 10.90 & 10.34 & 4.29 & 14.63 & 9.30 & 3.90 & 13.20 & 14.14 & 6.96 & 21.10 \\
\hline Hand weeding & 11.20 & 9.50 & 20.70 & 20.88 & 13.0 & 33.88 & 13.70 & 12.60 & 26.30 & 31.52 & 16.21 & 47.73 \\
\hline Unweeded & 50.70 & 17.40 & 68.10 & 96.36 & 23.89 & 120.25 & 57.80 & 23.40 & 81.20 & 105.53 & 49.51 & 155.04 \\
\hline F- Test & ** & $* *$ & $* *$ & $* *$ & ** & ** & ** & ** & ** & ** & ** & ** \\
\hline LSD 5\% & 0.77 & 0.45 & 2.14 & 2.52 & 1.06 & 2.49 & 0.93 & 0.85 & 1.57 & 2.16 & 1.33 & 2.84 \\
\hline
\end{tabular}


Agric. Biol. J. N. Am., 2010, 1(5): 992-1000

Table 3: Growth, yield, yield components and chemical composition as affected by nitrogen levels and weed treatments during $2007 / 2008$ and $2008 / 2009$ seasons (combined analysis of two seasons).

\begin{tabular}{|c|c|c|c|c|c|c|c|c|c|c|c|c|}
\hline \multirow[b]{2}{*}{ Treatments } & \multicolumn{2}{|c|}{ Growth } & \multicolumn{6}{|c|}{ Yield and yield components } & \multicolumn{4}{|c|}{ Chemical composition } \\
\hline & $\begin{array}{l}\text { Flag } \\
\text { leaf } \\
\text { area } \\
\left(\mathrm{cm}^{2}\right)\end{array}$ & $\begin{array}{c}\text { Plant } \\
\text { height } \\
\text { (cm) }\end{array}$ & $\begin{array}{c}\text { Spike } \\
\text { length } \\
(\mathrm{cm})\end{array}$ & $\begin{array}{c}\text { No. of } \\
\text { grains/ } \\
\text { spike }\end{array}$ & $\begin{array}{l}\text { Weight } \\
\text { of grains } \\
\text { Ispike } \\
\text { (g) }\end{array}$ & $\begin{array}{c}\text { No. of } \\
\text { spikes } / m^{2}\end{array}$ & $\begin{array}{l}\text { Grain yield } \\
\text { (ardab/fed) }\end{array}$ & $\begin{array}{c}\text { Straw } \\
\text { Yield } \\
\text { (ton/fed) }\end{array}$ & $\begin{array}{c}\text { Crud } \\
\text { Protein } \\
\%\end{array}$ & $\begin{array}{l}\mathbf{P} \\
\%\end{array}$ & $\begin{array}{l}\mathrm{K} \\
\%\end{array}$ & $\begin{array}{c}\text { Carboh- } \\
\text { ydrates } \\
\%\end{array}$ \\
\hline \multicolumn{13}{|l|}{ Nitrogen levels: } \\
\hline $15 \mathrm{~kg} \mathrm{~N} / \mathrm{fed}$ & 14.82 & 114.66 & 6.76 & 47.00 & 1.90 & 272.10 & 16.02 & 3.04 & 8.17 & 0.225 & 0.290 & 66.10 \\
\hline $30 \mathrm{~kg} \mathrm{~N} / \mathrm{fed}$ & 16.62 & 117.49 & 6.97 & 48.15 & 2.07 & 325.13 & 17.69 & 3.37 & 9.43 & 0.252 & 0.330 & 67.14 \\
\hline $45 \mathrm{~kg} \mathrm{~N} / \mathrm{fed}$ & 18.60 & 120.88 & 7.35 & 49.48 & 2.23 & 364.63 & 19.42 & 3.75 & 10.01 & 0.298 & 0.380 & 69.50 \\
\hline $60 \mathrm{~kg} \mathrm{~N} / \mathrm{fed}$ & 19.06 & 121.47 & 7.19 & 49.73 & 1.91 & 370.00 & 19.72 & 3.81 & 10.50 & 0.315 & 0.410 & 70.60 \\
\hline F-Test & ** & ** & ** & ** & $* *$ & ** & ** & ** & $* *$ & İNS & NS & $* *$ \\
\hline LSD 5\% & 2.29 & 2.96 & 0.38 & 2.10 & 0.081 & 6.92 & 0.18 & 0.20 & 0.49 & -- & -- & 0.92 \\
\hline \multicolumn{13}{|l|}{ Weed control: } \\
\hline Metosulam & 18.05 & 120.88 & 7.11 & 49.32 & 2.09 & 331.00 & 17.99 & 3.45 & 9.47 & 0.264 & 0.354 & 68.41 \\
\hline Sulfamoylurea & 16.94 & 119.75 & 7.00 & 47.76 & 1.94 & 324.00 & 17.61 & 3.31 & 9.35 & 0.245 & 0.344 & 67.91 \\
\hline Fenoxaprop-p- ethyl & 15.98 & 116.81 & 6.73 & 46.95 & 1.79 & 309.75 & 17.06 & 3.18 & 9.02 & 0.250 & 0.321 & 67.51 \\
\hline Clodinafop-propagyl & 16.31 & 116.50 & 6.88 & 47.43 & 1.78 & 316.50 & 17.32 & 3.25 & 8.97 & 0.267 & 0.315 & 67.36 \\
\hline Isoproturon.+Diflufinican & 20.06 & 124.80 & 7.88 & 51.13 & 2.42 & 404.00 & 22.25 & 4.15 & 10.66 & 0.317 & 0.415 & 71.21 \\
\hline Isoproturon & 18.81 & 123.38 & 7.59 & 50.56 & 2.34 & 384.00 & 21.68 & 4.07 & 10.47 & 0.310 & 0.397 & 70.61 \\
\hline Hand weeding & 22.45 & 122.13 & 7.21 & 49.36 & 2.14 & 338.00 & 18.41 & 3.53 & 10.02 & 0.297 & 0.376 & 69.21 \\
\hline Unweeded & 9.16 & 104.75 & 6.15 & 46.21 & 1.70 & 257.25 & 13.38 & 2.99 & 8.32 & 0.230 & 0.304 & 64.51 \\
\hline F- Test & $* *$ & $* *$ & $* *$ & $* *$ & $* *$ & $\star *$ & $* *$ & $* *$ & $* *$ & NS & NS & $* *$ \\
\hline LSD 5\% & 2.23 & 4.18 & 0.26 & 3.15 & 0.093 & 2.34 & 0.42 & 0.051 & 0.21 & -- & -- & 0.81 \\
\hline
\end{tabular}


Agric. Biol. J. N. Am., 2010, 1(5): 992-1000

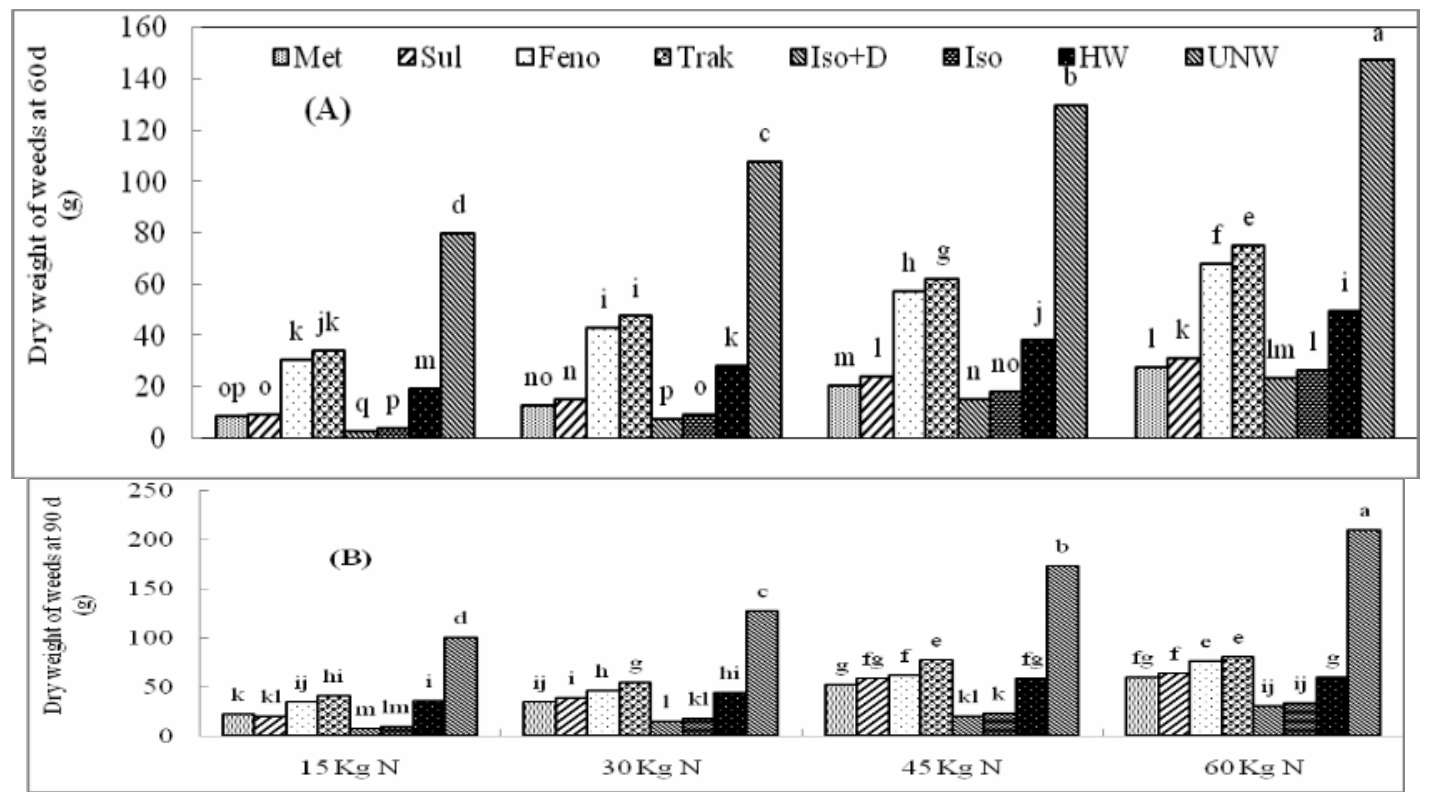

Fig. 1: Total dry weight of weeds after 60 (A) and 90 (B) days from sowing as affected by interaction between $\mathrm{N}$ - fertilizer levels and weed control treatments during 2007/2008 and 2008/2009 seasons (combined analysis of two seasons).

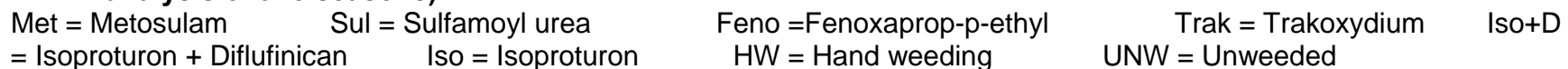

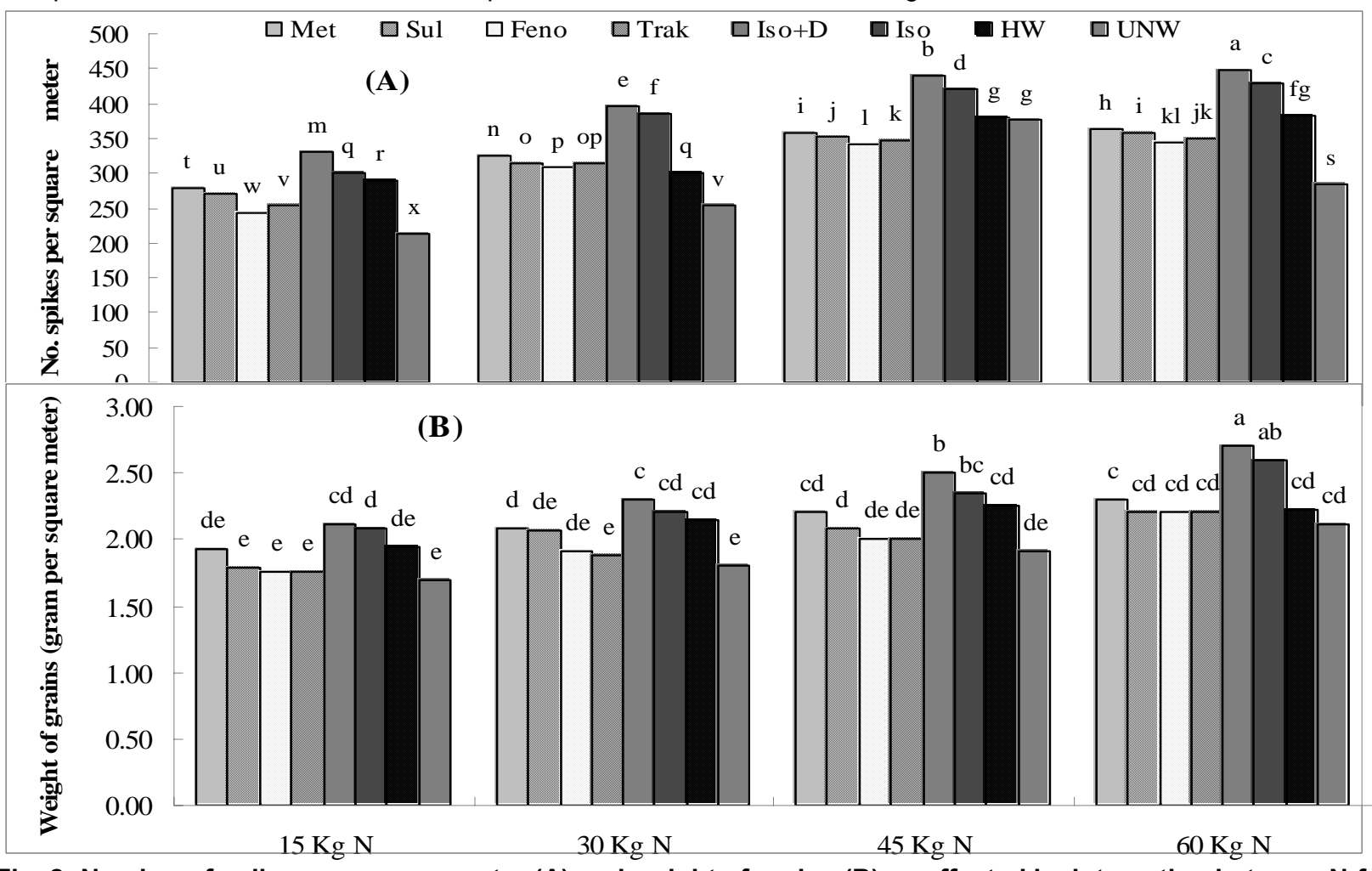

Fig. 2: Number of spikes per square meter (A) and weight of grains (B) as affected by interaction between $\mathrm{N}$-fertilizer levels and weed control treatments during 2007/2008 and 2008/2009 seasons (combined analysis of two seasons).

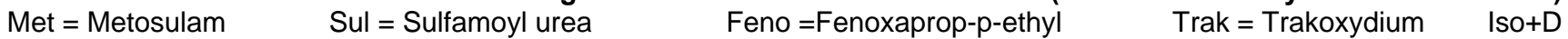
$=$ Isoproturon + Diflufinican $\quad$ Iso $=$ Isoproturon $\quad H W=$ Hand weeding $\quad N W=$ Unweeded 
Agric. Biol. J. N. Am., 2010, 1(5): 992-1000

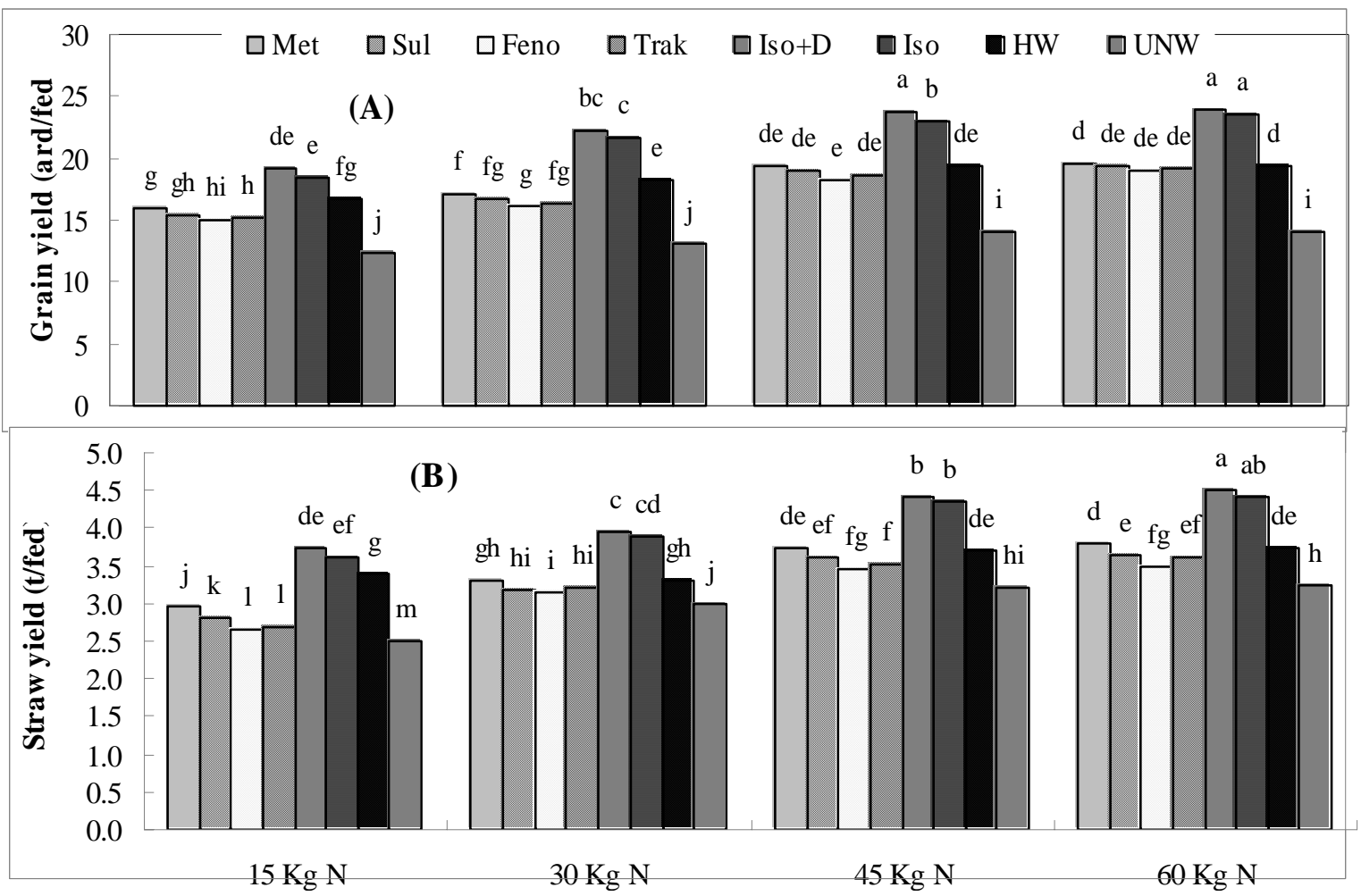

Fig. 3: Grain yield (A) and straw yield (B) as affected by interaction between $\mathrm{N}$ - fertilizer levels and weed control treatments during 2007/2008 and 2008/2009 seasons (combined analysis of two seasons).

$\begin{array}{lcccc}\text { Met }=\text { Metosulam } & \text { Sul }=\text { Sulfamoyl urea } & \text { Feno }=\text { Fenoxaprop-p-ethyl } & \text { Trak = Trakoxydium } & \text { Iso+D } \\ =\text { Isoproturon + Diflufinican } & \text { Iso }=\text { Isoproturon } & \text { HW }=\text { Hand weeding } & \text { UNW = Unweeded } & \end{array}$

Interaction effect: There was a significant effect of the interaction between nitrogen levels and weed control treatments on number of spikes $/ \mathrm{m}^{2}$, grain weight/spike, grain and straw yields (Figs. 2 and 3). The highest number of spikes $/ \mathrm{m}^{2}$, grain weight/spike, grain and straw yields/fed was recorded under $60 \mathrm{~kg} \mathrm{~N} / \mathrm{fed}$ and isoproturon + diflufinican treatment. While the lowest number of spikes $/ \mathrm{m}^{2}$, grain weight/spike, grain and straw yields was recorded when added of $15 \mathrm{~kg} \mathrm{~N} / \mathrm{fed}$ in unweeded treatment. Similar results were obtained by Metwally et al. (2000) and Turk et al. (2003).

\section{Chemical composition of barley grains:}

Effect of nitrogen levels: Averages of crude protein and carbohydrates percentage were appreciably influenced by $\mathrm{N}$ - levels in combined both seasons as shown in Table 3. In this respect, with each increase in nitrogen level there was a progressive increase in crude protein and carbohydrates content. Application of nitrogen at $60 \mathrm{~kg} \mathrm{~N} / \mathrm{fed}$ recorded the highest value of crude protein (10.5) and carbohydrate (70.6) percentages. On the other side, the lowest crude protein and carbohydrates percentages were recorded with 15 $\mathrm{kg} \mathrm{N} / \mathrm{fed}$. Nitrogen fertilizer encourage the absorption of nitrogen in the plant and this might be the cause of the obtained increase in crude protein and carbohydrates percentages. The same conclusion was mentioned by El-Metwally (1998) and El-Metwally (2002). Nitrogen fertilizer levels had insignificant effect on phosphorus and potassium percentages in barley grains.

Effect of weed management: As show in Table 3 all tested weed control treatments significantly improved protein and carbohydrates percentages of barley grains. The highest protein (10.7) and carbohydrates (71.2) percentages were obtained from isoproturon+ diflufinican treatment, followed by isoproturon, hand weeding and metosulam treatments, respectively. These results may be due to the less competition for nutrients, water and light through limiting weeds infestation with herbicidal and hand hoeing treatments due to increasing the uptake of different nutrients. In contrast, the lowest statistical values of aforementioned characters received by the unweeded treatment, recorded 8.32 and $64.51 \%$, respectively. Similar results were obtained by several workers Metwally et al. (2000) and El-Metwally (2002). Weed control treatments had 
insignificant effect on phosphorus and potassium percentages in barley grains.

It could be concluded that using $60 \mathrm{~kg} \mathrm{~N} / \mathrm{fed}$ resulted in increment of growth and productivity of barley crop when isoproturon + diflufinican treatment was used.

\section{REFERENCES}

Abd Alla, M. M. (2004). Influence of nitrogen level and its application time on yield and quality of some new hull less barley. J. Agric. Sci. Mansoura Univ., 29(5): $2201-$ 2216.

Abou El-Defan, T. A. and E. R. El-Desoki (2000). Response of some soil properties of clay loam soil and barley grain yield and associated weeds to some weed control treatments. J. Agric. Sci. Mansoura Univ., 25(7): 40574070.

Ali, M; S. Sabir; Q. Mohy-Ud-Din and M. A. Ali (2004). Efficacy and economics of different herbicides against narrow leaved weeds in wheat. Int. J. of Agric. and Bio., 6(4): 647-651.

A. O. A. C. (1980). Official methods of analysis (13 th Ed.) Association of Official Analytical Chemists. Washington, USA.

Bailey, W. and H. P. Wilson (2003). Control of Italian ryegrass (Lolium multiflorum) in wheat (Triticum aestivum L.) with postemergence herbicides. Weed Tech., 17(3): 534-542.

Blackshaw, R. E. and R. N. Brandt (2008). Nitrogen fertilizer rate effects on weed competitiveness is species dependent. Weed Sci., 56(5): 743-747.

Buker, R. S.; B. Rathinasabapathi; W. M Stall; G. MacDonald and S. M. Olson (2004). Physiological basis for differential tolerance of tomato and pepper to rimsulfuron and halosulfuron: Site of action study. Weed Sci., 52: 201-205.

Cottenie, A.; M.Verloo; L. Kiekens; G. Velghe and Camerlynck (1982). Chemical analysis of plant and soils. Lab. Agrochem. State Univ., Ghent, Belgium. P. 15-17.

Dubois, M.; K. A. Glles; J. K. Hamition and P. A. Rebers (1956). Colourimetric method for determination of sugars and related substances. Anal. Chem., 28: 350 -356.

El-Bawab, A. M. O. and A. O. Kholousy (2003). Effect of seeding rate and method of weed control on the productivity of Giza 2000, a promising barley line, under new lands condition. Egypt. J. of Agric. Res., 81(3):1085 1098.

El-Sheref, E. El. M.; A. M. Omar; A. A. El-Hag and A. M. Shahen (2007). Effect of some agricultural treatments on barley yield and some technological characters. J. Agric. Sci. Mansoura Univ., 32(3):1671-1690.

El-Metwally, I. M. (1998). Effect of herbicides and biofertilization on growth and yield of wheat under different nitrogen fertilizer levels. Ph. D. Thesis Fac. Agric. Mansoura Univ.

El-Metwally, I. M. (2002). Performance of some wheat cultivars and associated weeds to some weed control treatments. Zagazig J. Agric. Res., 29(6):1907-1927.

El-Metwally, I. M. and H.S. Soudy (2009). Herbicides tankmixtures efficiency on weeds and wheat productivity.
Annals of Agric. Sci. Moshtohor Benha Univ., 47(2): 95 109.

El-Metwally, I. M. and K. G. El-Rokiek (2007). Response of wheat plants and accompanied weeds to some new herbicides alone or combined in sequence. Arab Univ. J. Agric. Sci. Ain Shams Univ., 15:513 - 525.

Gomez, K. A. and A. A. Gomez (1984). Statistical Procedures for Agriculture Research. A Wiley- Inter Science Publication, John Wiley \& Sons, Inc. New York, USA.

Hussein, H. F. and E. R. El-Desoki (2001). Impact of weed control treatments and seeding rate on weeds and productivity on barley (Hordeum vulgare) plants. J. Agric. Sci. Mansoura Univ., 26(6):3677-3688.

Ivany, J.A. (2005). Response of three potato ( Solanum tuberosum) cultivars to pyrafluven-ethyl used as a desiccant in Canada. Crop Prot., 24:836 -841.

Khedr, A. H. and E. A. E. Nemeat Alla (2006). Response of barley to intercropping with sugar beet under different nitrogen fertilization levels. J. Agric. Sci. Mansoura Univ., 31(8):4957-4968.

Megahed, M. A. (2003). Effect of seeding rate and nitrogen fertilizer level on newly hull - less barley under sprinkler irrigation system in poor sandy soil at Ismailia Governorate. Egypt. J. Appl. Sci., 18(2):108 - 119.

Metwally, G. M.; A. A. A. Hassan and S. A. Ahmed (2000). Influence of some herbicides on barley yield and yield components and the common associated weeds. J. Agric. Sci. Mansoura Univ., 25(10):6009 - 6019.

Muhammad, A; M, Hussain; G. Hussain and A. Rashid (2007). Efficacy of different herbicides for weed control in wheat crop. Pak. J. Weed Sci. Res., 13(1-2):1-7.

Nassar, A. N. M. (2008). Response of two barley varieties to mineral and biological nitrogenous fertilizer and weed control treatments. J. Agric. Sci. Mansoura Univ., 33 (1): 29-51.

Ram, H.: H. S. Brar and U. S. Walia (2002). Investigations on the chemical control of wild oats (Avena ludoviciana Dur.) in irrigation barley (Hordeum vulgare L.). Indian J. of Weed Sci., 34(1/2): 24 -27.

Rashid, A. and R. U. Khan (2008). Comparative effect of varieties and fertilizer levels on barley (Hordeum vulgare). Int. J. of Agric. and Bio., 10(1):124 -126.

Singh, R. (2004). Influence of irrigation levels and diclofopmethyl on weed growth and yield of wheat (Triticum aestivum L.). Annals of Agric. Res. Indian, 25(2):306 -311.

Turk, M. A.; A. M. Tawaha; N. Samarah and N. Allataifeh (2003). The response of awnless six row barley (Hordeum vulgare L.) to nitrogen fertilizer application and weed control methods in the absence of moisture stress. Pak. J. Agron., 2:101-108.

WSSA, (Weed Science Society of America). (1994).

Herbicide Handbook (7 th Ed.) Champaign, Illinois, USA.

Youssef, S. A.; E. E. El-Sheref; A. A. El-Hag and R. A. A. Khder (2004). Effect of nitrogen fertilizer levels and biofertilization sources on two barley cultivars. J. Agric. Sci. Mansoura Univ., 29 (12): 6787-6808. 